\title{
Evaluation of Some Lentil Genotypes for Drought Tolerance in Context of Drought Tolerance Indices
}

\author{
J. Sen*, A.K. Pal and D. Dutta
}

Department of Plant Physiology, Bidhan Chandra Krishi Visvavidyalaya, Mohanpur, Nadia, West Bengal -741 245, India

*Corresponding author

\begin{abstract}
A B S T R A C T
\section{Keywords}

Drought Tolerance, Geometric mean productivity

Article Info

Accepted:

04 March 2019

Available Online:

10 April 2019

Lentil (Lens culinaris Medikus) is an important winter season grain legume crop, mostly grown on residual soil moisture and is frequently subjected to terminal drought and heat stress, that results in low and variable seed yields. Moreover, delay in sowing even for two weeks causes the reproductive and grain filling phase of this crop to coincide with a period of substantially high temperature resulting in yield losses by reduced seed set, seed weight and accelerated senescence. With this background, an experiment was conducted to study the effect of terminal drought and heat stress on some genotypes of lentil. The experiment was laid out in split plot design with three replication and the experiment was conducted in District Seed Farm, AB Block, Kalyani, Nadia. Data were recorded on seed yield and its important attributes like plant height, days to 1 st flower, days to $50 \%$ flowering, number of pod /plant, hundred seed weight shelling percentage [calculated as (seed wt/pod wt) $\times 100$ ] harvest index and days to harvest. And for harvest records five plants from each replication were randomly selected. Evaluation of lentil genotypes was done on basis of late sown (YS) and normal sown (YP) conditions and indexes of drought tolerance such as mean productivity (MP), tolerance against stress (TAS), geometric mean productivity (GMP), and stress tolerance index (STI).
\end{abstract}

\section{Introduction}

Lentil (Lens culinaris Medik.) is one of the most important winter season grain legumes cultivated in South Asia, West Asia, the Middle East, Southern Asia and South America. Globally, it is cultivated in an area of 3.85 million hectares with a production of 3.59 million tons (Kumar et al., 2013). India contributes nearly one-third of the world's annual production of lentil and assures the food and nutritional security of its burgeoning population one step ahead. But it is the fact that this grain legume is mostly cultivated on residual soil moisture in the arid and semiarid regions of the world and is frequently subjected to the curses of terminal heat and drought stress that causes in low and variable seed yields (Saxena, 1993 and Shrestha et al., 2006). Like other pulse crops, lentil is also very sensitive to the effects of high temperature stress at the reproductive stages of development.

Drought stress is a daunting challenge for successful crops production in many areas of the world, mainly in dryland areas. Water deficit affects almost all morphological and 
physiological traits that related to growth and decreased even 50\% crop yield (Wang et al.,2003).According to Oweis et al., (2004) drought stress reduced 6 to 54percentage of lentil yield and production functions relating lentil yield with field water supply under supplemental and rainfed conditions. Actually, when drought stress starts to influence on the plant at reproductive stage, the plant reduces the demand of photosynthate by reducing the size of sink. As a result, reduction in leaf size, stem extension and root proliferation occur and flower may drop, pollen may die and ovule may abort (Blum, 1996; Farooq et al., 2009). Even a few days of high temperature may cause flower and pod abortion, and that result in yield losses by reducing seed set, seed weight and accelerating senescence in this crop (Gaur et al., 2014).

Lentil the mostly preferred pulse in India, for its easily digestible protein content along with other nutritional qualities is predominantly grown in India in the Gangetic plains of West Bengal as rainfed crop on the residual soil moisture of preceding crop (rice in general). In these regions, the sowing of lentil is often delayed due to late harvesting of kharif paddy which often may result due to delayed and skewed rainfall pattern. Moreover, the recent trends in climate change and subsequent rise in global temperature have further intensified the threat of heat and drought stress for winter pulse crops including lentil. It is predicted that due to global climate change, the frequency and severity of drought events is expected to increase progressively in the future (Meehl and Tebaldi, 2004; Sheffield et al., 2012; Trenberth et al., 2014). Thus, it has become inevitable to study the effect of terminal heat and drought stress on seed yield and quality of lentil and to screen out genotype (s) showing thermo-tolerance at reproductive stage. Because it is the common concern that will shape the future climate resilience as well as food security by sustainable productivity in lentil through advanced breeding programmes. As it is known that heritability of yield in drought condition is low due to higher environmental and genotype interaction and lower genotypic variance. Several drought resistance indices will prove as important selection criterion. Therefore, to identify the best selection indices for drought tolerance in lentil under terminal drought conditions, this research was conducted under two sowing dates.

\section{Materials and Methods}

Nine genotypes of lentil were procured from germplasm of AICRP (MULLaRP) and ICARDA. They were sown on two different dates viz., $15^{\text {th }}$ November (normal) and $15^{\text {th }}$ December (late) in the year 2016. The experiment was laid out in split plot design with three replication and the experiment was conducted in District Seed Farm, AB Block, Kalyani, Nadia (latitude $22^{\circ} 58^{\prime}$ and longitude 8832 ). Climatically the site is under subtropical humid climate. The temperature and a rainfall amount from the onset of reproductive period till harvesting period was depicted in table 5. The soil texture of the experimental plot was sandy loam with $\mathrm{pH}$ 6.9-7.0. The row length was $1.5 \mathrm{~m}$ and a spacing of $25 \mathrm{~cm}$ was followed in between rows while plant to plant spacing was $15 \mathrm{~cm}$. Recommended management practices were followed to raise a healthy crop with basal fertilizer dose of $20-40-40 \mathrm{~kg} / \mathrm{ha}$. The crop was raised without application of any irrigation. From the weather data and data of soil water potential it is clear that the crop had faced drought and heat stress during reproductive period. The presence of little amount of rainfall during the grain development period was not sufficient to support the expression of full yield potential under un-irrigated condition. Data were recorded on seed yield and its important 
attributes like plant height, days to $1^{\text {st }}$ flower, days to $50 \%$ flowering, number of pod /plant, hundred seed weight shelling percentage [calculated as (seed wt/pod wt) $\times 100$ ] harvest index and days to harvest. And for harvest records five plants from each replication were randomly selected. Evaluation of lentil genotypes was done on basis of late sown (YS) and normal sown (YP) conditions and indexes of drought tolerance such as mean productivity (MP), tolerance against stress (TAS), geometric mean productivity (GMP), and stress tolerance index (STI) given in following:

Ysi $=$ yield of cultivar in stress condition, Ypi $=$ yield of cultivar in normal condition,

Drought tolerance efficiency $(\mathrm{DTE})=\mathrm{Ysi} / \mathrm{Ypi}$ $* 100$

Stress tolerance index (STI) = (Ypi*Ysi)/Ypi ${ }^{2}$ (Beguom et al., 1996)

Tolerance against stress $($ TAS $)=$ Ypi-Ysi (Farshadfar et al., 2001)

Geometric mean productivity (GMP) $=$ Ypi*Ysi (Fernandez et al.,1992)

Mean productivity $(\mathrm{MP})=(\mathrm{Ypi}+\mathrm{Ysi}) / 2$ (Fischer et al., 1987).

All data were calculated to analyses of variance according to Gomez and Gomez (1984). Significant means were separated by the Least Significant Difference (LSD) at the 0.05 significance level $(\mathrm{P} \leq 0.05)$. The estimation of correlation for traits was calculated by SPSS computer software package.

\section{Results and Discussion}

Analysis of variance and mean comparisons of Ysi (yield in late sown condition), Ypi (seed yield in normal sown condition) showed that, there were high significant differences $(p<0.05)$ between lentil lines, indicating presence of high genetic diversity among them. Effect of sowing dates and genotypes on seed yield was highly significant. Perusal of the data registered a decline in all genotypes in plant height, pod/pant, hundred seed weight, hundred pod weight, seed yield per plant and harvest index under $2^{\text {nd }}$ sowing date with exceptions of two genotypes, PL406 and RKL-604-01 that showed increased plant height in stressed condition. Considering all the yield components, a significant interaction was detected among genotypes and sowing dates, while for days to maturity, there was no significant interaction among genotype and sowing dates. There were considerable reduction in seed yield in delayed sowing.PL-406 was found to be the most susceptible under terminal heat and drought condition showing drastic reduction of $56.31 \%$ in seed yield than the normal sowing condition while only $18.71 \%$ decline in seed yield was recorded in the genotype ILL-6002 followed by RKL-604-01 (20.12\%) and L-4710 (20.22\%). The results were consistent with that of Azadi et al., (2013) and Seghal et al., (2017)who also reported yield loss due to delay in planting date. The two genotypes, viz., ILL-6002 and RKL-60401, also registered the least to moderate reduction in pod number per plant $(18.3 \%$ and $33.3 \%$ reduction, respectively, over normal sown condition) and in seed size expressed as hundred seed number $(10.6 \%$ and $15.8 \%$, respectively). The reduction in seed yield caused by a delay in sowing might also be attributed to the shorter growth period during late-sown condition, as the time taken for the crop to mature decreased with delay in sowing. This led to a reduction in seed weight which was reflected as reduction in seed size as well. This decline in seed yield or 100 seed size might be also attributed to low assimilate translocation under terminal heat and moisture stress condition. The terminal 
drought condition eventually caused lower harvest index in second sowing condition. The results were supported by the report that high temperatures during a short period reduced the seed number per pod and per plant in pea (Jeuffroy et al., 1990) and in lentil (Mishra et al., 2016). In the present experiment, ILL-6002 showed 6.77 percent reduction in $\mathrm{HI}$ as compared to normal sowing condition, where as $32.34 \%$ decline in HI was recorded by PL-406. The result was in accordance with the result of Ulemale et al., (2013) in chick pea. From the results, it might be suggested that PL-406 the most susceptible genotype, whereas ILL-6002 showed considerable tolerance under terminal heat and drought stress condition. The number of pods per plant and 100 seed weight were important determiner for seed yield (Table 1 and 2).

Based on yields of non-stress (Ypi) and stress (Ysi) conditions, several quantitative drought tolerance indices, such as mean productivity (MP), geometric mean productivity (GMP), drought tolerance efficiency (DTE) and stress tolerance index were used to evaluate the drought responses of the genotypes under study (Table 3). Higher DTE value reflected the more resilience in drought condition and it ranged from 43.69-81.28. On the basis of DTE, ILL-6002 (DTE=81.29) registered was found to be most suitable under late sown condition closely followed by RKL-604-01 (DTE=79.88) whereas PL-406 (DTE=43.69) was proved to be the most adversely affected genotypes showing least tolerance. A higher MP, GMP and STI value indicated more tolerance to drought stress (Fernandez, 1992; Gavuzzi et al., 1997; Hossain et al., 1990, Siahsar et al.,2010). In our study, these three indices were considered as best selection indices under late sown condition. Stress tolerance index (STI) varied significantly (2.59-.17) and genotype with high values indicated the highest tolerance to terminal drought condition. Genotypes ILL-6002 (STI=2.59) followed by RKL-604-01 (STI=1.59) and IPL-534 (STI=0.79) with high STI values indicated the tolerance towards the moisture stress while, genotypes, PL-406, ILL-60951, Subrata and L-4710 recording less than 0.50 values showed susceptibility to drought. Significant variability was also found among the genotypes in mean productivity (MP) and in geometric mean productivity (GMP). Genotype ILL-6002, RKL-604-01 and IPL-534 and WBL-77 with high MP value (greater than 1) indicated tolerance. On the contrary, the data indicated that PL-406 was most drastically affected under terminal stress with least GMP (0.489) and MPI (0.532).

Different drought indices probably measure similar aspect of drought tolerance / resistance but shows variation in between different sowing dates. Results obtained on mean yields of all the genotypes were evaluated under stress and non-stress (normal sown) conditions. Among the five selection indices, STI, GMP and MP showed significant correlation with seed yield under stressed condition whereas DTE and TAS were not significantly correlated with seed yield (Table 4). STI was proved more important selection criterion than DTE and TAS in late sowing condition having the value of $r=0.979$.GMP and MP were also correlated with each other and GMP established significant and high correlation with seed yield under stressed condition $(r=0.995)$. These results were consistent with the finding of Azizi Chakherchaman et al., (2009) in lentil that indicated that correlation of seed yield with MP, HM, GMP and STI indices was positive and significant under stress and non-stress conditions and to SSI index was negative and significant. Moreover, these results corroborated the early findings of Naroui Rad et al., (2009) in lentil and Khaghani (2008) in faba bean. 
Table.1 Mean comparison of different yield attributes for nine lentil genotypes under two different sowing dates

\begin{tabular}{|c|c|c|c|c|c|c|c|c|c|c|c|}
\hline Sowing Dates & $\begin{array}{l}\text { Days to } 1^{\text {st }} \\
\text { flower } \\
\text { (DAS) }\end{array}$ & $\begin{array}{l}\text { Days to } \\
\mathbf{5 0 \%} \\
\text { flower } \\
\text { (DAS) }\end{array}$ & $\begin{array}{l}\text { Plant ht } \\
(\mathrm{cm})\end{array}$ & $\begin{array}{l}\text { Pods/ } \\
\text { plant }\end{array}$ & $\begin{array}{l}\text { 100-pod } \\
\text { wt } \\
(\mathrm{g})\end{array}$ & $\begin{array}{l}\text { 100-seed } \\
\text { wt (g) }\end{array}$ & $\begin{array}{l}\text { Harvest } \\
\text { index } \\
(\%)\end{array}$ & $\begin{array}{l}\text { Seed } \\
\text { yield/plant } \\
\text { (g) }\end{array}$ & $\begin{array}{l}\text { Shelling } \\
\text { percentage }\end{array}$ & $\begin{array}{l}\text { Biomass/ } \\
\text { plant } \\
\text { (g) }\end{array}$ & $\begin{array}{l}\text { Days to } \\
\text { harvest } \\
\text { (DAS) }\end{array}$ \\
\hline $15^{\text {th }}$ Nov & 49.26 & 61.41 & 37.42 & 45.85 & 4.0207 & 2.0059 & 38.58 & 1.1874 & 49.69 & 5.6856 & 104.22 \\
\hline $15^{\text {th }}$ Dec & 49.48 & 57.70 & 35.43 & 27.89 & 2.7633 & 1.4585 & 28.83 & 0.8689 & 54.88 & 4.7681 & 91.15 \\
\hline $\mathrm{SE}(\mathrm{m}) \pm$ & 0.5520 & 0.6946 & 0.0188 & 0.4216 & 0.0257 & 0.0139 & 0.6857 & 0.0084 & 0.2771 & 0.0964 & 0.8433 \\
\hline $\mathrm{CD}(\mathrm{P}=0.05)$ & 0.0907 & 0.1142 & 0.0133 & 0.0693 & 0.0042 & 0.0023 & 0.1127 & 0.0014 & 1.2013 & 0.0158 & 0.1386 \\
\hline \multicolumn{12}{|l|}{ Genotypes } \\
\hline $\begin{array}{c}\text { Subrata } \\
\left(\mathbf{v}_{1}\right)\end{array}$ & 46.83 & 46.83 & 33.20 & 46.67 & 3.2117 & 1.5967 & 30.60 & 0.8233 & 49.93 & 4.7533 & 94.50 \\
\hline PL-406( $\left.v_{2}\right)$ & 57.50 & 57.50 & 36.25 & 27.00 & 2.7717 & 1.2783 & 20.41 & 0.5317 & 48.18 & 4.1517 & 110.33 \\
\hline $\begin{array}{c}\text { RKL-604- } \\
01\left(v_{3}\right)\end{array}$ & 45.67 & 45.67 & 33.52 & 45.00 & 3.8267 & 2.1883 & 44.18 & 1.5050 & 57.25 & 6.2033 & 98.83 \\
\hline L-4710 $\left(v_{4}\right)$ & 41.33 & 41.33 & 28.40 & 48.83 & 3.0250 & 1.4250 & 31.03 & 0.8000 & 84.50 & 4.5417 & 84.50 \\
\hline IPL-534(v $\left.{ }_{5}\right)$ & 55.17 & 55.17 & 40.72 & 31.67 & 3.3983 & 1.8300 & 31.53 & 1.0700 & 51.83 & 5.7217 & 99.17 \\
\hline ILL-6002( $\left(v_{6}\right)$ & 50.33 & 50.33 & 43.22 & 46.33 & 4.6583 & 2.6067 & 46.93 & 1.9217 & 58.52 & 7.4583 & 102.00 \\
\hline ILL-60951( $\left.v_{7}\right)$ & 52.00 & 52.00 & 35.89 & 28.83 & 2.9267 & 1.5750 & 30.92 & 0.7017 & 52.80 & 4.2283 & 96.50 \\
\hline $\operatorname{KLS}-218\left(v_{8}\right)$ & 51.67 & 51.67 & 38.75 & 29.67 & 2.8517 & 1.5017 & 35.49 & 0.8900 & 43.96 & 4.5733 & 100.83 \\
\hline WBL-77( $\left.\mathbf{v}_{9}\right)$ & 43.83 & 43.83 & 37.92 & 27.83 & 3.8583 & 1.5883 & 32.28 & 1.0100 & 51.11 & 5.4100 & 92.50 \\
\hline $\mathrm{SE}(\mathrm{m}) \pm$ & 1.8630 & 2.0890 & 0.6159 & 1.7848 & 0.1232 & 0.0665 & 1.3948 & 0.0439 & 1.6987 & 0.1262 & 3.1661 \\
\hline $\mathrm{CD}(\mathrm{P}=0.05)$ & 0.6468 & 0.7253 & 0.4356 & 0.6197 & 0.0428 & 0.0231 & 0.4843 & 0.0152 & 0.5897 & 0.0438 & 1.0992 \\
\hline
\end{tabular}


Table.2 Effect of interaction between sowing dates and genotypes for different yield attributes

\begin{tabular}{|c|c|c|c|c|c|c|c|c|c|c|c|}
\hline $\begin{array}{l}\text { Geno } \\
\text { types }\end{array}$ & $\begin{array}{c}\text { Days to } \\
1^{\text {st }} \\
\text { flower } \\
\text { (DAS) }\end{array}$ & $\begin{array}{c}\text { Days } \\
\text { to } \\
50 \% \\
\text { flower } \\
\text { (DAS) }\end{array}$ & $\begin{array}{l}\text { Plant ht } \\
\quad(\mathrm{cm})\end{array}$ & $\begin{array}{l}\text { Pods/ } \\
\text { plant }\end{array}$ & $\begin{array}{c}\text { 100-pod } \\
\text { wt } \\
(\mathrm{g})\end{array}$ & $\begin{array}{c}100- \\
\text { seed wt } \\
\text { (g) }\end{array}$ & $\begin{array}{c}\text { Harvest } \\
\text { index } \\
(\%)\end{array}$ & $\begin{array}{c}\text { Seed } \\
\text { yield/ } \\
\text { plant(g) }\end{array}$ & $\begin{array}{c}\text { Shelling } \\
\text { percentage }\end{array}$ & $\begin{array}{c}\text { Biomass/ } \\
\text { plant(g) }\end{array}$ & $\begin{array}{c}\text { Days to } \\
\text { harvest } \\
\text { (DAS) }\end{array}$ \\
\hline $\mathbf{V}_{1} \mathbf{S}_{1}$ & 48.67 & 58.00 & 34.40 & 55.33 & 3.6400 & 1.7667 & 38.15 & 0.9200 & 48.58 & 4.7500 & 101.00 \\
\hline$V_{2} S_{1}$ & 59.00 & 68.33 & 34.50 & 42.00 & 3.7233 & 1.5800 & 24.34 & 0.7400 & 42.41 & 5.2333 & 117.00 \\
\hline $\mathbf{V}_{3} S_{1}$ & 42.67 & 65.00 & 33.03 & 54.00 & 4.1700 & 2.3767 & 47.83 & 1.6733 & 57.01 & 6.6167 & 102.00 \\
\hline $\mathbf{V}_{4} \mathbf{S}_{1}$ & 41.67 & 50.00 & 29.80 & 59.67 & 3.4033 & 1.6700 & 35.92 & 0.8900 & 49.10 & 4.6800 & 93.00 \\
\hline$V_{5} S_{1}$ & 56.67 & 67.00 & 43.43 & 39.00 & 4.4267 & 2.1200 & 35.84 & 1.2367 & 47.88 & 6.2700 & 106.33 \\
\hline$V_{6} S_{1}$ & 49.67 & 66.00 & 44.43 & 51.00 & 4.9033 & 2.7533 & 48.58 & 2.1200 & 56.12 & 8.1000 & 110.00 \\
\hline$V_{7} S_{1}$ & 52.00 & 62.00 & 37.77 & 36.67 & 3.8633 & 1.9367 & 38.03 & 0.8033 & 50.12 & 4.3567 & 102.33 \\
\hline$V_{8} S_{1}$ & 48.00 & 60.33 & 39.60 & 41.00 & 3.7667 & 1.9300 & 40.04 & 1.0867 & 51.29 & 5.1767 & 106.33 \\
\hline$V_{9} S_{1}$ & 45.00 & 56.00 & 39.84 & 34.00 & 4.2900 & 1.9200 & 38.54 & 1.2167 & 44.74 & 5.9867 & 100.00 \\
\hline$V_{1} S_{2}$ & 45.00 & 52.00 & 32.00 & 38.00 & 2.7833 & 1.4267 & 23.05 & 0.7267 & 51.29 & 4.7567 & 88.00 \\
\hline $\mathbf{V}_{2} \mathbf{S}_{2}$ & 56.00 & 65.00 & 38.00 & 12.00 & 1.8200 & 0.9767 & 16.47 & 0.3233 & 53.95 & 3.0700 & 103.67 \\
\hline$V_{3} S_{2}$ & 48.67 & 54.67 & 34.00 & 36.00 & 3.4833 & 2.0000 & 40.53 & 1.3367 & 57.48 & 5.7900 & 95.67 \\
\hline$V_{4} S_{2}$ & 41.00 & 49.67 & 27.00 & 38.00 & 2.6467 & 1.1800 & 26.13 & 0.7100 & 64.93 & 4.4033 & 76.00 \\
\hline$V_{5} S_{2}$ & 53.67 & 67.00 & 38.00 & 24.33 & 2.3700 & 1.5400 & 27.22 & 0.9033 & 55.78 & 5.1733 & 92.00 \\
\hline$V_{6} S_{2}$ & 51.00 & 61.67 & 42.00 & 41.67 & 4.4133 & 2.4600 & 45.29 & 1.7233 & 60.92 & 6.8167 & 94.00 \\
\hline $\mathrm{V}_{7} \mathrm{~S}_{2}$ & 52.00 & 55.67 & 34.00 & 21.00 & 1.9900 & 1.2133 & 23.81 & 0.6000 & 55.47 & 4.1000 & 90.67 \\
\hline$V_{8} S_{2}$ & 55.33 & 59.67 & 37.90 & 18.33 & 1.9367 & 1.0733 & 30.94 & 0.6933 & 36.63 & 3.9700 & 95.33 \\
\hline$V_{9} S_{2}$ & 42.67 & 54.00 & 36.00 & 21.67 & 3.4267 & 1.2567 & 26.02 & 0.8033 & 57.48 & 4.8333 & 85.00 \\
\hline $\mathrm{SE}(\mathrm{m}) \pm$ & 0.8671 & 0.9737 & 0.5809 & 0.8291 & 0.0572 & 0.0309 & 0.6554 & 0.0204 & 0.7876 & 0.0605 & 1.4722 \\
\hline $\begin{array}{c}\text { CD } \\
(P= \\
0.05)\end{array}$ & 2.5281 & 2.8475 & 1.6742 & 2.4067 & 0.1658 & 0.0895 & 1.9499 & 0.0590 & 2.2771 & 0.1877 & 4.2821 \\
\hline
\end{tabular}


Table.3 Stress tolerance attributes for different promising lentil genotypes

\begin{tabular}{|c|c|c|c|c|c|}
\hline & DTE & STI & TAS & GMP & MP \\
\hline v1 & 78.99 & 0.47 & 0.19 & 0.818 & 0.823 \\
\hline v2 & 43.69 & 0.17 & 0.42 & 0.489 & 0.532 \\
\hline v3 & 79.88 & 1.59 & 0.34 & 1.496 & 1.505 \\
\hline v4 & 79.78 & 0.45 & 0.18 & 0.795 & 0.800 \\
\hline v5 & 73.04 & 0.79 & 0.33 & 1.057 & 1.070 \\
\hline V6 & 81.29 & 2.59 & 0.40 & 1.911 & 1.922 \\
\hline v7 & 74.69 & 0.34 & 0.20 & 0.694 & 0.702 \\
\hline v8 & 63.80 & 0.53 & 0.39 & 0.868 & 0.890 \\
\hline v9 & 66.02 & 0.69 & 0.41 & 0.989 & 1.010 \\
\hline
\end{tabular}

Table.4 Correlation factors among Drought tolerance indices and their sensitivity with grain yield under stress condition

\begin{tabular}{|l|l|l|l|c|c|}
\hline & STI & TAS & GMP & MP \\
\hline DTE & & 0.578 & 0.506 & -0.553 & 0.559 \\
\hline STI & & $.985^{* *}$ & 0.321 & $1.000^{* *}$ \\
\hline TAS & & & 0.348 & $.987 * *$ \\
\hline GMP & & & & 0.341 \\
\hline
\end{tabular}

Table.5 Soil water potential (MPa) for year: 2016-17

\begin{tabular}{|c|c|c|c|c|c|}
\hline Sowing Date & Soil Depth & 50DAS & 65DAS & 80DAS & 95DAS \\
\hline \multirow{2}{*}{$\begin{array}{c}\text { Normal sowing (15 } \\
\text { November) }\end{array}$} & $0-15 \mathrm{~cm}$ & -0.120 & -0.181 & -0.255 & -0.329 \\
\cline { 2 - 6 } & $15-30 \mathrm{~cm}$ & -0.130 & -0.464 & -0.225 & -0.532 \\
\cline { 2 - 6 } & $30-45 \mathrm{~cm}$ & -0.114 & -0.597 & -0.461 & -1.675 \\
\hline \multirow{2}{*}{$\begin{array}{c}\text { Late sowing (15 } \\
\text { December) }\end{array}$} & $0-15 \mathrm{~cm}$ & -0.255 & -0.329 & -2.750 & -3.278 \\
\cline { 2 - 6 } & $15-30 \mathrm{~cm}$ & -0.225 & -0.532 & -3.312 & -4.509 \\
\hline
\end{tabular}


Table.6 rainfall anad temperature data during the vegetative reproductive growth period of the crop lentil

\begin{tabular}{|c|c|c|c|}
\hline $\begin{array}{c}\text { Standard } \\
\text { meteorological } \\
\text { weeks }\end{array}$ & \multicolumn{2}{|c|}{ Temperature $\left({ }^{\circ} \mathbf{C}\right)$} & Rainfall \\
\cline { 2 - 4 } $\begin{array}{c}\text { Maximum } \\
\text { 46owing of } \\
\text { crop) }\end{array}$ & 29.58 & Minimum & mm \\
\hline $\mathbf{4 7}$ & 29.27 & 15.30 & 0.00 \\
\hline $\mathbf{4 8}$ & 29.36 & 16.57 & 0.00 \\
\hline $\mathbf{4 9}$ & 27.76 & 14.99 & 0.00 \\
\hline $\mathbf{5 0}$ & 25.30 & 10.80 & 0.00 \\
\hline $\mathbf{5 1}$ & 25.93 & 12.43 & 0.00 \\
\hline $\mathbf{5 2}$ & 25.49 & 13.43 & 0.00 \\
\hline $\mathbf{1}$ & 25.67 & 12.41 & 0.00 \\
\hline $\mathbf{2}$ & 24.13 & 10.59 & 0.00 \\
\hline $\mathbf{3}$ & 26.29 & 8.80 & 0.00 \\
\hline $\mathbf{4}$ & 27.66 & 11.81 & 0.00 \\
\hline $\mathbf{5}$ & 26.90 & 11.79 & 0.00 \\
\hline $\mathbf{6}$ & 29.64 & 13.43 & 0.00 \\
\hline $\mathbf{7}$ & 30.49 & 15.74 & 0.00 \\
\hline $\mathbf{8}$ & 31.86 & 18.59 & 0.00 \\
\hline $\mathbf{9}$ & 33.43 & 16.50 & 0.00 \\
\hline $\mathbf{1 0}$ & 31.43 & 19.29 & 0.46 \\
\hline $\mathbf{1 1}$ & 32.21 & 16.73 & 0.00 \\
\hline $\mathbf{1 2}$ & 33.80 & 21.86 & 0.81 \\
\hline $\mathbf{1 3}$ & 35.65 & 25.98 & 0.00 \\
\hline & & & \\
\hline
\end{tabular}

The STI also showed strong correlation with $\operatorname{GMP}(\mathrm{r}=0.985)$ and $\mathrm{MP}(\mathrm{r}=0.987)$ and this was in accordance with the results in fababean documented by Khaghani (2008).

In conclusion, the study revealed that drought tolerance indices should be chosen depending on the severity of the stress and in this study STI,MP,GMP were proven to be best suited selection parameters for lentil breeding. On the basis of these indicators ILL-6002 and RKL-604-01 were recorded as tolerant type whereas PL-406 showed most poor performance under late sown condition. But it should be kept in mind that, based on this limited sample and environments, testing and selection under non-stress and stress conditions alone may not be the most effective for increasing yield under drought stress. Moreover drought stress tolerance through conventional breeding is limited owing to its multigenic nature and complex mechanism involved (Athar and Ashraf 2009)So to improve yield in a stressed and non-stressed environments, it is necessary to focus on local adaptation to increase gains from selection concluded directly in that environment (Atlin et al., 2000; Hohls, 2001). However, selection should be based on the resistance indices calculated from the yield under both conditions, when the breeder is looking for the genotypes adapted for a wide 
range of environments or location with unpredictable conditions.

\section{Acknowledgement}

We thank AICRP (MULLaRP) and ICARDA for providing the seeds and other facilities and the first author is also thankful to ICAR for the financial support for the research work with ICAR senior research fellowship.

\section{References}

Athar, H. R., and Ashraf, M. (2009). Strategies for crop improvement against salinity and drought stress: An overview. In Salinity and water stress (pp. 1-16). Springer Netherlands.

Atlin, G.N., R.J. Baker, K.B. McRae and X. Lu, 2000.Selection response in subdivided target regions. Crop Sci., 40: 7-13.

Beguom, S. and Beguom, S. 1996.Morphogical study and character association in germplasm of lentil (Lens culinaris Medik). Bangladesh J. Botany 25:79-81.

Blum, A. (1996). Crop responses to drought and the interpretation of adaptation. Plant Growth Regulation, 20(2), 135-148.

Chakherchaman, S. A., Mostafaei, H., Imanparast, L., and Eivazian, M. R. (2009). Evaluation of drought tolerance in lentil advanced genotypes in Ardabil region, Iran. Journal of Food, Agriculture and Environment, 7(3/4), 283-288.

Farooq, M., Wahid, A., Kobayashi, N., Fujita, D., and Basra, S. M. A. (2009). Plant drought stress: effects, mechanisms and management. Agronomy for sustainable development, 29(1), 185-212.

Farshadfar, E., Zamani, M., Motallebi, M. and Imamjomeh, A. 2001.Selection for drought resistance in chickpea lines. Iranian $\mathrm{J}$. Agric. Sci. 32(1): 65-77.

Fernandez, G. C. J. (1992). Effective selection criteria for assessing plant stress tolerance. Proceeding of a Symposium, Taiwan, 13-18 Aug.257-270.

Fischer, R.A, and Maurer, R. (1987). Drought resistance in spring wheat cultivars. I. Grain yield response. Aust. J. Agric. Res. 29:897-
912.

Gavuzzi, P., Rizza, F., Palumbo, M., Campanile, R. G., Ricciardi, G. L., and Borghi, B. (1997). Evaluation of field and laboratory predictors of drought and heat tolerance in winter cereals. Canadian Journal of Plant Science, 77(4), 523-531.

Hohls, T., 2001. Conditions under which selection for mean productivity tolerance to environment stress, or stability should be used to improve year across a range of contrasting environments. Euphytica, 120: 235-245.

Hossain, A. B. S., Sears, R. G., Cox, T. S., and Paulsen, G. M. (1990).Desiccation tolerance and its relationship to assimilate partitioning in winter wheat. Crop Science, 30(3), 622-627.

http://www.plantstress.com/Articles/ drought_i/drought_i. htm.

irrigation in a Mediterranean environment. Agric. Water Manag.68(3): 251-265.

Jeuffroy MH, Duthion C, Meynard JM, Pigeaire A. 1990. Effect of a short period of high day temperature during flowering on the seed number per pod of pea Pisum sativum L. Agronomie 2: 139-145.

Khaghani, S., M.R. Bihamta, F. Rahim and H.R. Dorry 2008.Study of qualitative and quantitative traits in red bean in non-stress and drought conditions. Asian J. Plant Sci., 7(6): 563-568.

Kumar S., P. Thakur, N. Kaushal, J. A. Malik, P. Gaur, and H. Nayyar. (2013). Effect of varying high temperatures during reproductive growth on reproductive function, oxidative stress and seed yield in chickpea genotypes differing in heat sensitivity. Archives Agronomic Soil Sciences,59:823-43.

M.C. Saxena (1993ed.), Food Security and Climate Change in Dry Areas. Proceedings of International Conference. Syria: ICARDA; pp 244-254.

Meehl, G. A., and Tebaldi, C. (2004). More intense, more frequent, and longer lasting heat waves in the 21st century. Science, 305(5686), 994-997.

Mishra, B. K., Srivastava, J. P., Lal, J. P., and Sheshshayee, M. S. (2016). Physiological and biochemical adaptations in lentil 
genotypes under drought stress. Russian journal of plant physiology, 63(5), 695-708.

Naroui Rad, M. R., Abbasi, M. R., and Fanaei, H. R. (2009). Evaluation of drought stress tolerance with use of stress tolerance indexes in sorghum collected germplasms national plant gene bank of Iran. Agronomy.

Oweis, T., A. Hachum and M. Pala. 2004. Lentil production under supplemental

Sehgal, A., Sita, K., Kumar, J., Kumar, S., Singh, S., Siddique, K. H., and Nayyar, H. (2017). Effects of Drought, Heat and Their Interaction on the Growth, Yield and Photosynthetic Function of Lentil (Lens culinaris Medikus) Genotypes Varying in Heat and Drought Sensitivity. Frontiers in Plant Science, 8, 1776.

Sheffield, J., Wood, E. F. and Roderick, M. L. (2012). Little change in global drought over the past 60 years. Nature, 491(7424), 435438.

Shrestha, R., Turner, N. C., Siddique, K. H. M., Turner, D. W. and Speijers, J. (2006). A water deficit during pod development in lentils reduces flower and pod numbers but not seed size. Australian Journal of Agricultural Research, 57(4), 427-438.

Siahsar, B. A., Ganjali, S., and Allahdoo, M. (2010). Evaluation of Drought Tolerance Indices and Their Relationship with Grain Yield of Lentil Lines in Drought stressed and Irrigated Environments. Australian Journal of Basic and Applied Sciences, 4(9), 4336-4346.

Trenberth, K. E., Dai, A., Van Der Schrier, G., Jones, P. D., Barichivich, J., Briffa, K. R., and Sheffield, J. (2014). Global warming and changes in drought. Nature Climate Change, 4(1), 17-22.

Ulemale, C.S., Mate S.N. and Deshmukh, D.V. (2013). Physiological Indices for Drought Tolerance in Chickpea (Cicer arietinum L.).World Journal of Agricultural Sciences, 9 (2): 123-131.

Vahidi, H., Rajabi, A., Hadi, M. R. H. S., Taleghani, D. F., and Azadi, A. (2013). Screening of sugar beet (Betavulgaris L.) genotypes for drought tolerance. International Journal of Agriculture and Crop Sciences, 6(16), 1104.

Varshney, R. K., Thudi, M., Nayak, S. N., Gaur, P. M., Kashiwagi, J., Krishnamurthy, L., and Rathore, A. (2014). Genetic dissection of drought tolerance in chickpea (Cicer arietinum L.). Theoretical and Applied Genetics, 127(2), 445-462.

Wang, W., B. Vinocur and A. Altman. 2003. Plant responses to drought, salinity ande xtreme temperatures: towards genetic engineering for stress tolerance. Planta. 218:1-14.

\section{How to cite this article:}

Sen, J., A.K. Pal and Dutta, D. 2019. Evaluation of Some Lentil Genotypes for Drought Tolerance in Context of Drought Tolerance Indices. Int.J.Curr.Microbiol.App.Sci. 8(04): 363372. doi: https://doi.org/10.20546/ijcmas.2019.804.040 